\title{
CONSIDERAÇÕES EM TÔRNO DO ATO ADICIONAL
}

Ao se iniciar o período regencial, achava-se na sua culminância a anarquia que bem caracterizou grande parte do Primeiro Império. Os motins que perturbaram os primeiros anos de nossa vida independente, não haviam sido de todo estirpados; muitos continuaram a ameaçar a Regência, constituindo-se numa das mais desagradáveis heranças que o reinado de D. Pedro I legou aos seus continuadores.

“Os movimentos provinciais, quando não erán nitidamente separatistas, abriam mão de qualquer auxílio vizinho e não se preocupavam mesmo da possibilidade da sua extensão. Daí a maior diversidade nos principios invocados. Iam desde a República e a separação aité : a Monarquia Constitucional ou a criação de algum govêrno diferente para a espera da maioridade de D. Pedro" (1).

Não menos difícil e perigosa era a situação econômica do país. As conseqüências prejudiciais para a nossa economia, decorrentes do retôrno de $\mathrm{D}$. João VI para Portugal, juntaram-se os males da decadência atingida pela mineração e a conhecida crise da cana de açúcar. O retrato dêsse panorama econômico, teve por moldura, a crescente quebra do poder aquistivo interno, e a tendência dos antigos senhores de engenho, em obter assistência do Estado. Esse clima econômico servia muitas vêzes para a difusão de ideais revolucionários, filhos de desassombrada paixão nativista, ou melhor diriamos, regionalista. A Regência não dispunha de meios que pudessem varrer do solo pátrio, a semente da conspiração e da quebra do sentimento de unidade nacional. A idéia de federação foi abraçada pelos exaltados, quer com Monarquia, quer com República, indiferentemente. Os moderados eram monarquistas, sem declarar com firmeza, se desejavam Monarquia Unitária ou Monarquia Federativa. Desde que se concebeu a idéia de que os desatinos politicos eram responsáveis pelo desequilíbrio econômico-financeiro, admitiu-se que consertando-se aquê-

(1). - Nelson Werneck Sodré, Panorama do Secundo Império, pág. 269. 
les, fic'aria reparado êste último. Aventou-se portanto a idéia de reforma da Constituição. Estavam errados entretanto, aquêles que pensavam encontrar nesse caminho, a estrada que os levaria à solução dos problemas econômicos.

Na sessão de 6 de maio de 1831, a Câmara dos Deputados recebeu o requerimento de Cesário de Miranda Ribeiro, solicitando a nomeação de uma comissão que se encarregaria da reforma constitucional. Tal requerimento tomava por justificativa, o artigo 174 da Constituição que dizia:

"A Constituição pode ser reformada decorridos 4 anos e, feita a proposta da reforma parcial em uma legislatura, só na seguinte será ela definitivamente aprovada".

Uma vez aprovado o requerimento, foi eleita a comissão que apontaria os artigos da constituição que por necessidade deveriam ser modificados. Constituiram-na Paula Souza, Costa Carvatho e o deputado requerente. A comissão concluiu seu trabalho dois meses depois; ao projeto um tanto complexo no tocante à organização do poder legislativo, se interpuseram outras propostas. A preferência da Casa entretanto recaiu sôbre o trabalho da comissão designada, quando se realizaram as discussões seguintes. O próprio Miranda Ribeiro apresentou novo substitutivo. Este, aprovado, foi tomado como diretriz das discussões subseqüentes. Algumas emendas se the fizeram, considerando-se terminada a tarefa da Câmara que o aprovara. Em seguida foi remetido para o Senado. Como a Câmara Vitalícia o receberia? Calógeras (2), nos esclarece o conceito que se fazia da Câmara Alta:

'Tinba-se o Senado por uma assembléia reacionária: ali se achavam todos os antigos conselheiros absolutistas de D. Pedro I, e sòmente uma minoria era liberal. Barbacena, Vergueiro e Caravelas figuravam entre êstes últimos. Era geral a opinião de que a maioria não deixaria votar a lei, com receio da federação".

E mais adiante acrescenta:

"Feijó, um liberal que quase se manifestava republicano, era então Ministro da Justiça (...) Feijó, cuja energia não se preocupava com a legalidade e confinava com a violênciạ, planejou eliminar a Câmara Alta da cooperação no elaborar a lei preliminar sôbre a reforma constitucional. Entre os deputados, entretanto, sentava-se Honório Hermeto Carneiro Leão, o futuro Marquês do Paraná, um dos mais eminentes, serenos e adian-

(2). - J. Pandiá Calógeras, Formação Histórica do Brasil, págs. 146-147. 
tados estadistas do Brasil.. Fêz cair a proposta por inconstitucional e revolucionária, com o fito de conservar ao Estatuto sua plena fôrça e vigor".

O projeto de reformas que foi da Câmara para o Senado, oferecia as seguintes proposições: 1) o govêrno do Império será uma monarquia federativa; 2) a Constituição reconhecerá sòmente três poderes políticos; 3 ) a Constituição marcará distintamente as atribuições que competem ao poder legislativo; as que competem à assembléia nacional sem a concorrência de outro ramo dêste poder; as que competem a cada uma das câmaras que compõem a assembléia nacional, e as que são comuns a ambas as câmaras, fazendose nas respectivas atribuições as alterações que forem convenientes; 4) a Câmara dos Deputados renovar-se-á por eleições de dois em dois anos, formando êstes o período de cada legislatura; 5 ) a Câmara dos Senadores será eletiva e temporária: será renovada na terça parte de seus membros tôdas as vêzes que se renovar a Câmara dos Deputados; 6) passarão para o poder executivo as atribuições do poder moderador que convier conservar, sendo as outras suprimidas; 7) o poder executivo só poderá negar sanção às leis declarando por escrito os motivos: se, apesar disso, ambas as câmaras declararem que o projeto deve passar, será êle promulgado como lei; 8) será 'suprimido na Constituição o capítulo relativo ao Conselho de Estado; 9) os conselhos gerais de província serão convertidos em Assembléias Legislativas, compostas de duas câmaras; as leis que elas fize'rem, em assunto de sua competência, terão vigor nas respectivas províncias com a sanção dos presidentes; 10) as rendas públicas serão divididas em nacionais e provinciais, e serão fixadas respectivamente pela assembléia nacional e pelas assembléias provinciais; 11) durante a minoridade do Imperador, será o Império governadn por um regente; ou vice-regente, eleitos pelas assembléias provinciais do Império e feita a apuração dos votos pela assembléia nacional; 12) nos municípios haverá um intendente, que terá, no âmbito municipal, as mesmas atribuições que os presidentes nas províncias.

Essas doze proposições evidenciam com tôda a clareza que a mentalidade imperante na Câmara dos Deputados era federalista. As reformas sugeridas iam de encontro à opinião de que as províncias almejavam autonomia. Nem seria necessário oferecer às discussões os doze artigos, pois o primeiro, por si só, bastaria para alterar tôda a estrutura política do país e implicava, em si, nas me-didas contidas em todos os demais.

"Se vingasse na integra êsse projeto, não há dúvida que se poderiam julgar triunfantes aquêles que pretendiam constituir no Erasil "uma República presidida por um Imperador" (3).

(3). - Rocha Pombo, História do Brasil, vol. III, pag. 305. 
Em maio de 1832, a comissão do Senado, para tal designada, principiou a opinar sôbre os dizeres do projeto. Reconhecia perfeitamente que a Constituição carecia de reformas, conceito êsse estribađo nos interêsses regionais que òbviamente existem num país extenso como o Brasil.

Em face do artigo constitucional que dizia ser de uma legislatura a compatência de declarar a necessidade de reforma, e de outra legislatura a tarefa de realizá-la pela maneira como se estava procedendo, ficaria esta última legislatura sem função nessa matéria. Tal proceder era lógico porque a assembléia que estava apontando a natureza e os têrmos da reforma, só deixaria para a assembléia seguinte $o$ ato de confirmar a atitude de sua antecessora. Terminado seu trabalho, revelou o Senado que riscara do projeto da Câmara dos Deputados, na íntegra, nove dos doze artigos. conservando apenas os de números 3,9 e 10, e ainda assim com modificações. Lançou dessa maneira água fria na fervura dos ultrafederalistas.

Agora podem ser melhor compreendidas as raizes do plano Feijó para. a derrubada do Senado. O Marquês do Paraná foi o artífice da pacificação; de sua mente lúcida saiu a reflexão que o momento requeria; prudência foi o lema que se lhe afigurou imperativo. Câmara e Regência se irmanam para discutir as emendas do Senado. Sintoma de que a revolução esmorecera. Em assembléia geral se desenvolveram muitas sessões em setembro de 1832; a maior parte das emendas do Senado foi aprovada. A 12 de outubro foi sancionada a lei que serviu de modêlo para a promulgação do Ato Adicional. Com ela, veio a éra de calmaria política que se evidenciou pelo ano de 1833. Testemunharam-na as palavras com que se abriu a nova legislatura em maio de 1834. Dois dias depois, a 5 do referido mês, Henrique de Rezende solicitou a eleição de uma comissão qué deveria apresentar a "redação das $\mathbf{R e}$ formas da Constituição...".

Foram eleitos Limpo de Abreu, Paula Araújo e Bernardo Pereira de Vasconcelos. Levantou-se a questão da colaboração ou não da outra Câmara no assentamento das reformas. Chegou-se à conclusão de que competia sòmente à Câmara decretar as reformas. Os vinte e quatro artigos do projeto com várias emendas, deram origem à lei adicional à Constituição ( 21 de agôsto). Os artigos que haviam provocado mais demoradas discussões foram os de números um e seis. O primeiro por exemplo, acarretou comentários no tocante à "exclusão da jurisdição provincial, do município onde estivesse a côrte". O de número seis, provocou acaloradas discus-. sões em tôrno das ."imunidade parlamentares". 
Eis em resumo, os pontos fundamentais do Ato Adicional: estabeleceriam-se assembléias em tôdas as províncias do Império. O município em que estivesse a côrte, ficaria fora da jurisdição da assembléia legislativa da província a que pertencia. Estabeleceriamse os números dos membros componentes das assembléias provinciais; São Paulo e Rio de Janeiro por exemplo contariam com 36 membros; a maioria das províncias 20 representantes; os números poderiam ser alterados por lei geral. A eleição dêsses membros obedeceria ao critério adotado para a escôlha dos deputados gerais. Dois anos seria a duração de cada legislatura, sendo permitida a reeleição. Referia o Ato, o que devia caber a cada assembléia provincial propor, discutir e deliberar sem ferir os artigos da Constituição; e mais: discriminava o que lhes cabia legislar. Esclarecia as atribuições dos presidentes de províncias em relação às assembléias e seus atos. Declarou-se que durante a minoridade do Imperador, o país teria no govêrno uma regência una eleita pelos eleitores da respectiva legislatura, pelo espaço de quatro anos. Suprimiu-se o Conselho de Estado.

O Ato Adicional fôra entretanto aplicado com certo excesso. A experiência e o tempo foram seus denunciadores. Foi preciso discutir e votar uma Lei Interpretativa (1839-1840), que restringiu certas atribuições dos municípios bem como dispositivos relativos aos empregos públicos e judiciais. A $10^{\circ}$ de outubro de 1834, no encerramento das Câmaras, assim se expressou a Regência:

"A importante lei das reformas da Constituição politica do Império, reclamadas pelo bem geral e necessidades das províncias, devida ao vosso patriotismo e maduras reflexôes, tem seguramente de tornar inabaláveis a liberdade e a independência nacional, fortemente escudadas pela monarquia representativa...".

Na concepção de seus autores deveria o Ato Adicional ser como que um instrumento mantenedor duma política amistosa entre a centralização monárquica e os reclamos federalistas das províncias. Com êle se pensou outorgar ao país, a paz há muito esperada. Julgava-se, ainda, que com êle se desenvolveria em todo o país uma atmosfera construtiva para a sua economia tão abalada. Pena que êsse fôsse o mesmo pensar da classe culta da nação. In. felizmente, tomava-se como conseqüência o que não passava simplesmente de causa dos acontecimentos. Diríamos pois que o Ato Adicional foi desnecessário. Não corrigiu muitos males. Não trouxe essa árvcre crescida em mau terreno, a menor sombra de tranqüilidade. A prova têmo-la nos novos levantes e sedições que abalaram a ordem durante as duas regências que se seguiram ao Ato 
Adicional, entre os quais a Sabinada, a Balaiada, a Guerra dos Farrapos. E' mais do que evidente que as agitações que repetidamente explodiram, tiveram causas econômicas. A tão propalada descentralização, deveria considerar, antes de tudo, a situação econômica do país. Paulatinamente viriam, em seguida, as normas da descentralização política. O que o Ato Adicional deu às províncias foi portanto, uma falsa autonomia, um paupérrimo paliativo. O país não se ressentia dos efeitos de sua parca produtividade e diminuido poder aquisitivo? Então, na liberdade econômica estaria plasmada a liberdade político-administrativa das províncias.

O Ato Adicional fôra feito para pacificar o Brasil. Não deu certo entretarito; concorreu para acomodar melhor o antigo estado rebelde. Basta lembrar que jamais poderia haver entendimento $e$ construção, enquanto existisse um grave contraste: assembléias provinciais em choque com os governadores nomeados pelo govêrno central.

Assim se expressou Azevedo Amaral em $O$ Estado Autoritário e a Realidade Nacional, sôbre os efeitos do Ato Adicional:

"A Constituição de 1824 permitia o desenvolvimento de um sistema, baseado nessa distribuição da função politica e da atuação econômica, em que o municipio e a provincia cooperariam sinèrgicamente, o primeiro, animando a expansão da consciência política do Brasil unido, e a segunda, tornando-se propulsora eficiente das fôrças económicas do país. O Ato Adicional veio dar às provincias a função anti-nacional de núcleos políticos regionais. Na tradição administrativa que se firmou no Império, a centralização excessiva do "conîrôle" das questões econômicas nȩ̧ava às luidades provinciais a liberdade de ação nessa matéria, tolhando-lhes assim as iniciativas precisamerte no plano em que lhes devia caber a maior autonomia possivel".

Os erros do Ato Adicional, tornaram necessário a Lei de Interpretação. Até então, pecara pela demasiada autonomia concedida às províncias. Esta, um tanto obscura, se tornou aclarada pela Lei de Interpretação. Não resta a menor dúvida de que ela foi o elo da ccesão política da nação. Afastava-se a tendência de predomínio das assembléias provinciais sôbre a Constituição ou ao Poder Central.

Mas não foi exclusivamente a referida Lei que realizou a integridade política do Brasil. Esta foi, antes, a obra formidável de Caxias. 